OPEN ACCESS

Edited by:

Yoshiro Maru,

Tokyo Women's Medical University,

Japan

Reviewed by:

Namir Shaabani,

The Scripps Research Institute,

United States

Jianzhong Zhu,

Yangzhou University, China

*Correspondence:

Sunghoon Kwon

skwon@snu.ac.kr

Amos C. Lee

amoslee89@snu.ac.kr

${ }^{\dagger}$ These authors have contributed equally to this work and share first authorship

Specialty section:

This article was submitted to

Viral Immunology,

a section of the journal

Frontiers in Immunology

Received: 29 January 2021 Accepted: 06 May 2021

Published: 19 May 2021

Citation:

Lee $A C$, Jeong $Y$, Lee $S$, Jang $H$, Zheng A, Kwon S and Repine JE (2021) Nasopharyngeal Type-I Interferon for Immediately Available

Prophylaxis Against Emerging Respiratory Viral Infections.

Front. Immunol. 12:660298. doi: 10.3389/fimmu.2021.660298

\section{Nasopharyngeal Type-I Interferon for Immediately Available Prophylaxis Against Emerging Respiratory Viral Infections}

\author{
Amos C. Lee ${ }^{1 *+}$, Yunjin Jeong ${ }^{1 \dagger}$, Sumin Lee ${ }^{2}$, Haewook Jang ${ }^{3}$, Allen Zheng ${ }^{4}$, \\ Sunghoon Kwon ${ }^{2,3,5,6,7 *}$ and John E. Repine ${ }^{8}$
}

${ }^{1}$ Bio-MAX Institute, Seoul National University, Seoul, South Korea, ${ }^{2}$ Department of Electrical and Computer Engineering, Seoul National University, Seoul, South Korea, ${ }^{3}$ Interdisciplinary Program in Bioengineering, Seoul National University, Seoul, South Korea, ${ }^{4}$ Department of Microbiology, Icahn School of Medicine at Mount Sinai, New York, NY, United States, 5 Institute of Entrepreneurial Bio Convergence, Seoul National University, Seoul, South Korea, ${ }^{6}$ Seoul National University Hospital Biomedical Research Institute, Seoul National University Hospital, Seoul, South Korea, ${ }^{7}$ Center for Medical Institute, Seoul National University Hospital, Seoul, South Korea, ${ }^{8}$ Webb-Waring Center, University of Colorado School of Medicine, Aurora, CO, United States

In addition to SARS-CoV-2 and its variants, emerging viruses that cause respiratory viral infections will continue to arise. Increasing evidence suggests a delayed, possibly suppressed, type 1 interferon (IFN-I) response occurs early during COVID-19 and other viral respiratory infections such as SARS and MERS. These observations prompt considering IFN- $\beta$ as a prophylactic or early intervention for respiratory viral infections. A rationale for developing and testing intranasal interferon beta (IFN- $\beta$ ) as an immediately available intervention for new respiratory viral infections that will arise unexpectedly in the future is presented and supported by basic and clinical trial observations. IFN- $\beta$ prophylaxis could limit the spread and consequences of an emerging respiratory viral infection in at-risk individuals while specific vaccines are being developed.

Keywords: prophylaxis, emerging respiratory viral infection, type-I interferon, nasopharyngeal, post-pandemic, coronavirus, COVID-19

\section{INTRODUCTION}

COVID-19 is in the spotlight now but new viral respiratory infections will likely, and regrettably, cause morbidity and mortality globally in the future (1). The clinical presentation following COVID-19 and other respiratory viral infections varies widely; however, many patients become critically ill and die. They frequently develop the acute respiratory distress syndrome (ARDS) and multiple organ failure (2)-disorders that require, but are not counteracted well by, ventilator support, high oxygen concentrations, extracorporeal membrane oxygenation, pharmacologic treatment, and/or extraordinary supportive care in intensive care units. These findings mandate considering ways to prevent the severe or fatal consequences of serious viral respiratory infections.

Despite laudable progress in treating respiratory viruses that was accelerated by efforts to combat COVID-19, when new viral pandemics emerge, shortages of beds, equipment, drugs, human resources, and specific vaccines will unfortunately again most likely contribute to poor patient 
outcomes. We anticipate a need for safe, prophylactic therapeutic strategies that can prevent or blunt the initial progression of future novel respiratory viral infections that will arise at times when existing improved therapies and vaccines may not provide complete, enduring, specific, and/or immediately accessible protection (Figure 1A). Virus induced impairment of innate immunity certainly facilitated the launch of the SARS-CoV-2 global pandemic that caused severe infection and death before proper therapies or specific vaccines were developed and tested. Regrettably, it could happen again with a new virus. In addition, a substantial number of individuals may choose to not become vaccinated and will remain susceptible. Accordingly, prophylaxis methods must be immediately available for the emerging respiratory viral infections, even though innate immunity can to some degree limit some viral diseases and delay severe infection or death before proper therapies or vaccine options are developed for the new diseases.

The possibility of administering IFN-I prophylactically to healthy individuals at higher risk of respiratory viral infections could have beneficial consequences. IFN-Is, which include IFN- $\alpha$ and IFN- $\beta$, are critical components of innate immunity and the initial cytokines produced by cells during viral infection. Because these interferons are produced during a viral infection, they undoubtedly play a major role in the initial innate antiviral immune response. As a frontline component of human immunity, IFN-1 is expressed by host cells in response to pathogens, induces expression of interferon-stimulated genes (ISGs), and initiates basic protective responses by immune cells. Since the first description of IFNs in 1957, IFN-1 has been suggested as a treatment for various viral and immune-related diseases, including multiple sclerosis (MS), viral hepatitis, and seasonal influenza.

The potential of IFN-1 as a treatment for viral respiratory infections is strongly suggested by the limited IFN-1 responses of SARS-CoV-2-infected patients $(3,4)$. The COVID-19 experience demonstrated that patients with SARS-CoV-2 are both (a) very susceptible to IFN-I and (b) uniquely adept at evading endogenous IFN-I by delaying or suppressing IFN-I expression
(3-7). The ability of SARS-CoV-2 to inhibit endogenous IFN-I expression appears to make interferon pathway dysregulation critical to developing severe disease (5). Also, IFNs induce apoptosis of type II alveolar cells that are infected by viruses $(6,7)$. Moreover, when analyzing the transcriptomes, IFN-1 and IFN-3 levels are downregulated and innate antiviral responses are diminished in SARS-CoV-2 patients (8). Infection with SARS-CoV-2 produces a greater reduction in IFN-1 expression in host cells compared to the original severe acute respiratory syndrome coronavirus (SARS-CoV) (9). SARS-CoV-2 and SARS-CoV share over $90 \%$ amino acid identity but the proteins, which antagonize IFNs (nsp3, ORF3b, ORF6), have low sequence homology (10). ORF3b of SARS-CoV-2 has a premature stop codon that generates a truncated protein; ORF6b is missing two amino acids at the C-terminus and has decreased function. In addition, blood plasmacytoid dendritic cells from COVID-19 patients have impaired IFN-I generation (11). Collectively, SARS-CoV-2 can reduce IFN-I production by host cells and impair a protective early anti-viral response. Correcting these abnormalities could explain the enhanced susceptibility of SARS-CoV-2 to exogenous IFN-1 treatment. Not confining to SARS-CoV-2, the anti-interferon actions are observed in other respiratory infectious viral disease like Influenza A virus (12). Viral induced damage to the human respiratory, neurological, and other systems is often accompanied by IFN-I impairment (13).

We here describe a perspective on considering IFN- $\beta$ as a potential prophylactic and early intervention measure against respiratory virus infection such as COVID-19 for healthy people (Figure 1B). The biology of IFN- $\beta$ and pathology of SARS-CoV2 are briefly described, several ongoing clinical trials are reviewed (Table 1), and the need for clinical trials based on the preventive use of IFN- $\beta$ emphasized as they relate to future respiratory viral infections. Also, because the use of IFN-I may cause negative as well as positive effects, we describe previously reported adverse effects that the IFN-I may cause. IFN-I has long been used clinically, and we suspect that the nasopharyngeal delivery of
A

Prophylactic intervention needs to be highly accessible

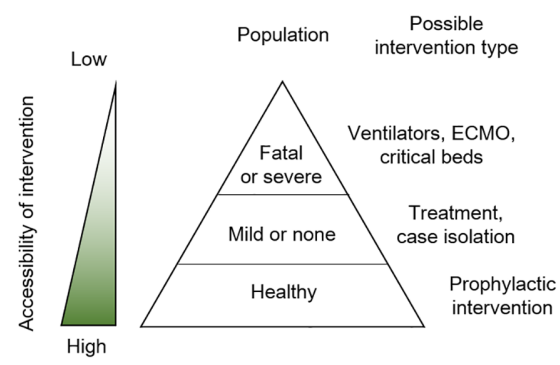

B

Interferon-beta in a drop as an antiviral prophylactic intervention

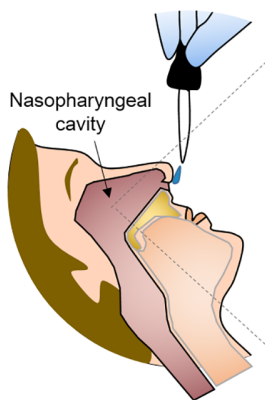

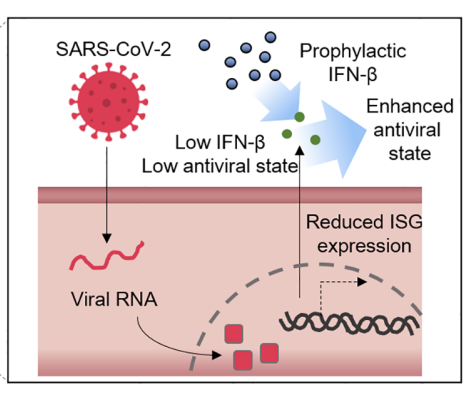

FIGURE 1 | Delivery of type I interferon-beta (IFN- $\beta$ ) to the nasopharyngeal cavity is a candidate prophylactic and early intervention measure against COVID-19 that has high potential for success. (A) A greater accessibility of the intervention can prevent shortages of ventilators, extracorporeal membrane oxygenation (ECMO) machines, and/or critical care beds. (B) Suggested in this perspective is the highly accessible delivery of IFN- $\beta$ to the nasopharyngeal cavity. The administered IFN- $\beta$ can partially compensate for reduced interferon-stimulated gene (ISG) expression in SARS-CoV-2-infected cells as way to enhance antiviral immunity. 
TABLE 1 | Clinical trials and results of IFN treatment.

\begin{tabular}{|c|c|c|c|c|c|c|}
\hline Disease & IFN-type & Participants & Delivery method & Effect & Side effect & Reference \\
\hline COVID-19 & $\mathrm{IFN}-\alpha$ & 2944 & Nasal drop & + & None & (14) \\
\hline COVID-19 & IFN- $\beta-1 b$ & 127 & Subcutaneous & + & None & (15) \\
\hline SARS & IFN- $\alpha$ & 190 & Subcutaneous & - & None & (16) \\
\hline MERS & IFN- $\alpha-2 a$ & 44 & Subcutaneous pegylated IFN & + & None & (17) \\
\hline MERS & IFN- $\alpha-2 b$ & 2 & Subcutaneous pegylated IFN & + & None & (18) \\
\hline MERS & IFN- $\alpha-2 b$ & 6 & Subcutaneous & + & None & (19) \\
\hline MERS & IFN- $\alpha-2 b$ & 5 & Subcutaneous & - & Hard to define & (20) \\
\hline MERS & $\mathrm{IFN}-\alpha, \beta$ & 51 & Subcutaneous & + & Not reported & (21) \\
\hline MERS & IFN- $\alpha-2 a, \beta-1 a$ & 24 & Subcutaneous & + & Not reported & (22) \\
\hline MERS & IFN- $\alpha-2 a, \beta-1 a$ & 11 & Subcutaneous & + & Not reported & (23) \\
\hline MERS & IFN- $\alpha-2 b$ & 2 & Subcutaneous pegylated IFN & + & Not reported & (24) \\
\hline MERS & IFN- $\alpha-2 a$ & 1 & Subcutaneous & + & Not reported & (25) \\
\hline MERS & $\mathrm{IFN}-\alpha-2 \mathrm{a}$ & 1 & Subcutaneous & - & Not reported & (26) \\
\hline Multiple sclerosis & IFN- $\beta-1 b$ & 2220 & Subcutaneous & + & $\begin{array}{l}\text { Flu-like symptoms and abnormalities in } \\
\text { liver function }\end{array}$ & $(27)$ \\
\hline Multiple sclerosis & IFN- $\beta-1 \mathrm{a}$ & 1106 & Subcutaneous & + & $\begin{array}{l}\text { Influenza-like illness, injection-site } \\
\text { reactions, thyroid disorders, hepatic } \\
\text { disorders }\end{array}$ & (28) \\
\hline Multiple sclerosis & IFN- $\beta-1 a$ & 383 & Subcutaneous & + & Depression, influenza-like syndrome & (29) \\
\hline Multiple sclerosis & IFN- $\beta-1 b$ & 338 & Subcutaneous & + & Not reported & (30) \\
\hline Multiple sclerosis & IFN- $\beta-1 a, 1 b$ & 188 & Subcutaneous & + & Not reported & (31) \\
\hline
\end{tabular}

IFN-I will have less adverse effects than the widely used subcutaneous doses.

\section{INTRANASAL IFN- $\beta$ ADMINISTRATION MAY BE A DESIRABLE OPTION FOR INITIALLY TREATING EMERGING RESPIRATORY VIRUS INFECTIONS}

Intranasal administration of IFN-I is attractive since respiratory viruses infect humans through the nasopharynx which initially harbors high viral loads (32-34). Intranasal administration of IFN$\alpha$ was reported to reduce seasonal influenza A virus morbidity in ferrets (35). Similarly, intranasal administration of IFN-I was shown to be effective in humans for prophylaxis against COVID-19. When recombinant human IFN- $\alpha$ was given as intranasal drops 4 times/ day for 28 days to 2,944 (2,415 in the low-risk group, 529 in the high-risk group) healthy medical staff members, no symptomatic SARS-CoV-2 infection or adverse effects were reported in either group, while comparable hospitals had $\sim 10 \%$ infection rate (14). Although not an official clinical trial, this observation offers promise that intranasal IFN-I prophylaxis could be effective when administered during the early stages of viral infection.

Because it is difficult to predict which antiviral will be best for prophylaxis of future respiratory viruses, extensive investigation of IFN- $\beta$, by which the exogenous administration seems to be more effective in inducing antiviral effect than IFN- $\alpha$, is important to conduct now. IFN- $\beta$ has been shown to induce stronger antiviral activity than IFN- $\alpha$ and is likely to be a more effective antiviral candidate than IFN- $\alpha$ for inhibiting coronaviruses (5, 22, 36-38). A recent clinical study of IFN- $\beta$ as a prophylaxis against COVID-19 yielded meaningful results. On July 20, 2020, Synairgen plc (Southampton, United Kingdom) announced phase II results on
101 patients showing the odds of developing severe COVID-19 are reduced by $79 \%$ in patients receiving inhaled IFN- $\beta$ treatment compared to placebo treatment. Moreover, COVID-19 patients receiving nebulized IFN- $\beta$ are more than twice as likely to recover (39). Furthermore, rare genetic variants in TLR7 that impair IFNB1 upregulation were identified in young men who developed severe COVID-19 (40). Despite the rising appreciation of the antagonism of IFN-I by SARS-CoV-2 (41), little investigation is being conducted to determine whether intranasal IFN-I can provide effective prophylaxis against SARS-CoV-2 and other respiratory viral infections. Ideally, these efforts could prospectively resolve manufacturing, pharmacokinetic, safety, efficacy, and other issues before a serious virus becomes widespread.

However, it is important that IFN-I should be used cautiously. For example, administration of IFN-I in high doses to patients may enhance cytokine storm and immunopathology. Especially, some of the side-effects previously reported in subcutaneously injected IFN- $\beta$ include flu-like symptoms, depression, thyroid dysfunction, liver enzymes abnormalities, skin-site reactions, immediate post-injection reaction, lipoatrophy, hair loss, cardiotoxicity, and fatigue (42). However, these are reported in the clinical trials for treating MS and are injected subcutaneously. In clinical trials for treating viral infectious diseases like COVID19, SARS, or MERS, little adverse effects have been reported (Table 1). Although more studies need to be conducted to why there are less adverse effects reported in viral infectious diseases, we suspect that the low levels of IFN- $\beta$ in severe patients infected by coronaviruses have an effect (43). Therefore, because safety is the most important parameter for prophylaxis, we propose that IFN- $\beta$ prophylaxis should be used by healthy people for preventing infections from emerging respiratory viruses to minimize the adverse effects of the IFN- $\beta$ prophylaxis.

The fact that IFN- $\beta$ appears to have little adverse effects for the respiratory infections in the literature (14-21, 23-31) 
(Table 1) is an important factor in selecting and preparing a candidate for emerging respiratory viral infectious diseases. Since IFN- $\beta$ may provide its greatest impact as a preventive measure in at-risk individuals, the safety of IFN- $\beta$ is important factor in selecting a candidate for treating emerging respiratory viral infectious diseases. Like in the COVID-19 pandemic, when a new respiratory viral infection emerges, options for emergency treatment are selected from the best available previously used drugs. IFN- $\beta$ is not only already used for treating respiratory viral infections, but also currently being tested for use by pregnant women to treat COVID-19. IFN- $\beta$ is assigned to a pregnancy category while most of the currently available treatment or vaccines are not (44). There were concerns in safety raised by the overexpression of the angiotensin-converting enzyme 2 (ACE2), the receptor in humans for virus entry for COVID-19. However, this concern was attenuated by reports that interferons induce a novel truncated ACE2 isoform, instead of the full-length receptor (45). Together, with the fact that IFN- $\beta$ has long been proposed for immune-related diseases as well as the respiratory viral infectious diseases, IFN- $\beta$ will also be a good temporary immediately available prophylactic counter measure for viral respiratory infections.

\section{IFN- $\beta$ NEEDS TO BE EVALUATED AS AN INTRANASAL ADMINISTERED PROPHYLACTIC OR EARLY INTERVENTION AGAINST RESPIRATORY VIRUSES}

Developing a formulation of IFN- $\beta$ to counter the high viral loads when they are invading the intranasal mucosa is rationale (46). Intranasal delivery could be relatively more effective than systemic injections $(47,48)$. Lower IFN- $\beta$ doses administered with a local or topical application can provide a relatively high drug concentration in a key location (49). In a recent clinical study by Synairgen, IFN- $\beta$ treatment of chronic obstruction pulmonary disease patients aged 60 or higher showed very little adverse effects, substantiating that using IFN- $\beta$ in high dosages might provide a safe prophylactic solution for preventing a viral respiratory infection. Considering the high viral loads that manifest early in the nasopharyngeal cavity, rigorous investigation to determine the value of delivering IFN- $\beta$ directly into the nose should be undertaken. Some examples of intranasal delivery include nasal drops, nasal sprays, and nasal creams. The biophysical stability and manufacturing cost of IFN- $\beta$ must be overcome but overcoming these and other hurdles will be worthwhile (50). Subsequently, clinical trials of IFN- $\beta$ as a prophylactic and early intervention for respiratory viruses should be performed to determine if this approach could counter the rapid spread and reduce the consequences of a highly infectious virus. In addition to social isolation and masking, treating individuals with IFN- $\beta$ could alleviate their symptoms, reduce the likelihood of the progression to more severe disease and, most importantly, reduce transmission.

\section{IFN- $\beta$ TREATMENT RESPONSES MAY DIFFER ACCORDING TO DISEASE SEVERITY AND HOST IMMUNE STATUS}

IFN- $\beta$ might be therapeutically effective in patients with severe symptoms but the greatest value might derive from early treatment of relatively asymptomatic individuals. Brzoska and his associates suggested that IFN- $\beta 1$ a should be provided to patients with severe symptoms due to coronavirus infections (49). In August 2020, a clinical trial sponsored by the National Institute of Allergy and Infectious Diseases (NIAID) began testing a combination of remdesivir and IFN- $\beta$ in patients with laboratory-confirmed COVID-19 with evidence of lung involvement and severe symptoms. However, IFN- $\beta$ has proinflammatory effects and may be contraindicated for treating patients with severe COVID-19 since robust IFN- $\beta$ responses may occur in patients with severe COVID-19 (3, 51-53). A hyperinflammatory signature, with strongly upregulated expression of TNF $\alpha$ - and IL-1-driven inflammatory responses and vigorous IFN-1 responses, occurs in patients with severe, but not mild, COVID-19, suggesting that IFN-1 might accelerate progression from mild to severe disease by stimulating inflammation $(11,52,53)$. Consequently, for patients who are in the later stages of COVID-19 with severe symptoms and/or organ damage, IFN- $\beta$ may not be preferable to other treatments. Patients with severe symptoms can also develop autoimmunity with IFN- $\alpha$ although this rarely occurs with IFN- $\beta$ (54). IFN-I treatment delivered via nebulizers produced better results as an early rather than an late stage intervention (55). Comparing the clinical outcomes of IFN- $\beta$ treated patients with mild and severe viral respiratory infection should preferentially be performed only after evaluating prophylactic or early IFN- $\beta$ treatment.

\section{CONCLUSION}

Mutants of SARS-CoV-2 have recently been recognized (56). In spite of the controversy regarding the efficacy against the SARSCoV-2 variants of the newly created vaccines, the lessons learned from the COVID-19 pandemic underscore the need to be better prepared for emerging respiratory infectious viruses. Although intranasal prophylaxis of IFN- $\beta$ has neither proven safety nor efficacy in healthy population, it may be a universal solution for emerging respiratory viral infections. Treating healthy people with IFN- $\beta$ during the initial phases of a viral infection outbreak could enhance protection beyond that afforded by mucosal immunity, physical isolation, and masks alone. Employing multiple interventions to prevent viral transmission is being promoted by the Imperial College COVID-19 Response Team to forestall and limit the overwhelming demands and ramifications caused by a pandemic respiratory viral infection (DOI: https://doi.org/10. 25561/77482). It is reasonable to forecast that new respiratory infectious diseases will arise in the future and, accordingly, developing antiviral prophylaxis strategies now would provide a more favorable, timely, and prudent course of action while new specific vaccines and therapies are being developed (49). 


\section{DATA AVAILABILITY STATEMENT}

The original contributions presented in the study are included in the article/supplementary material. Further inquiries can be directed to the corresponding authors.

\section{AUTHOR CONTRIBUTIONS}

AL, YJ, SL, HJ, AZ, SK, and JR designed the concept and wrote the manuscript. All authors contributed to the article and approved the submitted version.

\section{REFERENCES}

1. Wang C, Horby PW, Hayden FG, Gao GF. A Novel Coronavirus Outbreak of Global Health Concern. Lancet (2020) 395:470-3. doi: 10.1016/S0140-6736 (20)30185-9

2. Wu C, Chen X, Cai Y, Xia J, Zhou X, Xu S, et al. Risk Factors Associated With Acute Respiratory Distress Syndrome and Death in Patients With Coronavirus Disease 2019 Pneumonia in Wuhan, China. JAMA Intern Med (2020) 180:934. doi: 10.1001/jamainternmed.2020.0994

3. Blanco-Melo D, Nilsson-Payant BE, Liu WC, Uhl S, Hoagland D, Møller R, et al. Imbalanced Host Response to SARS-CoV-2 Drives Development of COVID-19. Cell (2020) 181:1036-45.e9. doi: 10.1016/j.cell.2020.04.026

4. Walz L, Cohen AJ, Rebaza AP, Vanchieri J, Slade MD, Dela Cruz CS, et al. JAKInhibitor and Type I Interferon Ability to Produce Favorable Clinical Outcomes in COVID-19 Patients: A Systematic Review and Meta-Analysis. BMC Inf Dis (2021) 21:47. doi: 10.1186/s12879-020-05730-z

5. Hadjadj J, Yatim N, Barnabei L, Corneau A, Boussier J, Smith N, et al. Impaired Type I Interferon Activity and Inflammatory Responses in Severe COVID-19 Patients. Science (2020) 369:718-24. doi: 10.1126/science.abc6027

6. Qian Z, Travanty EA, Oko L, Edeen K, Berglund A, Wang J, et al. Innate Immune Response of Human Alveolar Type II Cells Infected With Severe Acute Respiratory Syndrome-Coronavirus. Am J Respir Cell Mol Biol (2013) 48:742-8. doi: 10.1165/rcmb.2012-0339OC

7. Ziegler CGK, Allon SJ, Nyquist SK, Mbano IM, Miao VN, Tzouanas CN, et al. SARS-Cov-2 Receptor Ace2 Is an Interferon-Stimulated Gene in Human Airway Epithelial Cells and Is Detected in Specific Cell Subsets Across Tissues. Cell (2020) 181:1016-35.e19. doi: 10.1016/j.cell.2020.04.035

8. O'Brien TR, Thomas DL, Jackson SS, Prokunina-Olsson L, Donnelly RP, Hartmann R. Weak Induction of Interferon Expression by SARS-CoV-2 Supports Clinical Trials of Interferon Lambda to Treat Early Covid-19. Clin Infect Dis (2020) 71:1410-2. doi: 10.1093/cid/ciaa453

9. Lokugamage K, Hage A, de Vries M, Valero-Jimenez A, Schindewolf C, Dittmann M, et al. Type I Interferon Susceptibility Distinguishes SARS-CoV2 From SARS-Cov. J Virol (2020). 94:e01410-20. doi: 10.1128/JVI.01410-20

10. Park A, Iwasaki A. Type I and Type Iii Interferons - Induction, Signaling, Evasion, and Application to Combat Covid-19. Cell Host Microbe (2020) 27:870-8. doi: 10.1016/j.chom.2020.05.008

11. Arunachalam PS, Wimmers F, Mok CKP, Perera RAPM, Scott M, Hagan T, et al. Systems Biological Assessment of Immunity to Mild Versus Severe COVID-19 Infection in Humans. Science (2020) 369:eabc6261. doi: 10.1126/ science.abc6261

12. Kochs G, García-Sastre A, Martínez-Sobrido L. Multiple Anti-Interferon Actions of the Influenza A Virus NS1 Protein. J Virol (2007) 81:7011-21. doi: 10.1128/jvi.02581-06

13. Iadecola C, Anrather J, Kamel H. Effects of COVID-19 on the Nervous System. Cell (2020) 183:16-27. doi: 10.1016/j.cell.2020.08.028

14. Meng Z, Wang T, Chen L, Chen X, Longti L, Qin X, et al. An Experimental Trial of Recombinant Human Interferon Alpha Nasal Drops to Prevent Coronavirus Disease 2019 in Medical Staff in an Epidemic Area. medRxiv (2020) 2020.04.11.20061473. doi: 10.1101/2020.04.11.20061473

15. Hung IFN, Lung KC, Tso EYK, Liu R, Chung TWH, Chu MY, et al. Triple Combination of Interferon beta-1b, Lopinavir-Ritonavir, and Ribavirin in the

\section{FUNDING}

This work was supported by the National Research Foundation of Korea (NRF) grant funded by the Korea government (MSIT) (2020M3H1A1073304, NRF-2020R1A3B3079653).

\section{ACKNOWLEDGMENTS}

We acknowledge David I. Cohen and Samuel White, M.D. for giving advices on the manuscript.

Treatment of Patients Admitted to Hospital With COVID-19: An OpenLabel, Randomised, Phase 2 Trial. Lancet (2020) 395:1695-704. doi: 10.1016/ S0140-6736(20)31042-4

16. Zhao Z, Zhang F, Xu M, Huang K, Zhong W, Cai W, et al. Description and Clinical Treatment of an Early Outbreak of Severe Acute Respiratory Syndrome (SARS) in Guangzhou, Pr China. J Med Microbiol (2003) 52:715-20. doi: 10.1099/jmm.0.05320-0

17. Omrani AS, Saad MM, Baig K, Bahloul A, Abdul-Matin M, Alaidaroos AY, et al. Ribavirin and Interferon alfa-2a for Severe Middle East Respiratory Syndrome Coronavirus Infection: A Retrospective Cohort Study. Lancet Infect Dis (2014) 14:1090-5. doi: 10.1016/S1473-3099(14)70920-X

18. Al-Qaseer M. The Most Effective Therapeutic Regimen for Patients With Severe Middle East Respiratory Syndrome Coronavirus (Mers-CoV) Infection. J Infect Dis Ther (2015) 3:223. doi: 10.4172/2332-0877.1000223

19. Khalid M, Khan B, Al Rabiah F, Alismaili R, Saleemi S, Rehan-Khaliq AM, et al. Middle Eastern Respiratory Syndrome Corona Virus (Mers CoV): Case Reports From a Tertiary Care Hospital in Saudi Arabia. Ann Saudi Med (2014) 34:396-400. doi: 10.5144/0256-4947.2014.396

20. Al-Tawfiq JA, Momattin H, Dib J, Memish ZA. Ribavirin and Interferon Therapy in Patients Infected With the Middle East Respiratory Syndrome Coronavirus: An Observational Study. Int J Infect Dis (2014) 20:42-6. doi: 10.1016/j.ijid.2013.12.003

21. Al Ghamdi M, Alghamdi KM, Ghandoora Y, Alzahrani A, Salah F, Alsulami A, et al. Treatment Outcomes for Patients With Middle Eastern Respiratory Syndrome Coronavirus (Mers CoV) Infection At a Coronavirus Referral Center in the Kingdom of Saudi Arabia. BMC Infect Dis (2016) 16:174. doi: 10.1186/s12879-016-1492-4

22. Shalhoub S. Interferon beta-1b for COVID-19. Lancet (2020) 395:1670-1. doi: 10.1016/S0140-6736(20)31101-6

23. Khalid I, Alraddadi BM, Dairi Y, Khalid TJ, Kadri M, Alshukairi AN, et al. Acute Management and Long-Term Survival Among Subjects With Severe Middle East Respiratory Syndrome Coronavirus Pneumonia and ARDS. Respir Care (2016) 61:340-8. doi: 10.4187/respcare.04325

24. Khalid M, Al Rabiah F, Khan B, Al Mobeireek A, Butt TS, Al Mutairy E. Ribavirin and Interferon- $\alpha 2 b$ as Primary and Preventive Treatment for Middle East Respiratory Syndrome Coronavirus: A Preliminary Report of Two Cases. Antivir Ther (2015) 20:87-91. doi: 10.3851/IMP2792

25. Kim UJ, Won EJ, Kee SJ, Jung SI, Jang HC. Combination Therapy With Lopinavir/Ritonavir, Ribavirin and Interferon-a for Middle East Respiratory Syndrome. Antivir Ther (2016) 21:455-9. doi: 10.3851/IMP3002

26. Malik A, El Masry KM, Ravi M, Sayed F. Middle East Respiratory Syndrome Coronavirus During Pregnancy, Abu Dhabi, United Arab Emirates, 2013. Emerg Infect Dis (2016) 22:515-7. doi: 10.3201/eid2203.151049

27. O'Connor P, Filippi M, Arnason B, Comi G, Cook S, Goodin D, et al. $250 \mu \mathrm{g}$ or $500 \mu \mathrm{g}$ Interferon beta-1b Versus $20 \mathrm{Mg}$ Glatiramer Acetate in RelapsingRemitting Multiple Sclerosis: A Prospective, Randomised, Multicentre Study. Lancet Neurol (2009) 8:889-97. doi: 10.1016/S1474-4422(09)70226-1

28. Comi G, De Stefano N, Freedman MS, Barkhof F, Polman CH, Uitdehaag BMJ, et al. Comparison of Two Dosing Frequencies of Subcutaneous Interferon beta-1a in Patients With a First Clinical Demyelinating Event Suggestive of Multiple Sclerosis (REFLEX): A Phase 3 Randomised Controlled Trial. Lancet Neurol (2012) 11:33-41. doi: 10.1016/S1474-4422(11)70262-9 
29. Jacobs LD, Beck RW, Simon JH, Kinkel RP, Brownscheidle CM, Murray TJ, et al. Intramuscular Interferon Beta-1a Therapy Initiated During a First Demyelinating Event in Multiple Sclerosis. N Engl J Med (2000) 343:898904. doi: 10.1056/NEJM200009283431301

30. Duquette P, Girard M, Despault L, DuBois R, Knobler RL, Lublin FD, et al. Interferon beta-1b is Effective in Relapsing-Remitting Multiple Sclerosis. I. Clinical Results of a Multicenter, Randomized, Double-Blind, PlaceboControlled Trial. Neurology (1993) 43:655-61. doi: 10.1212/wnl.43.4.655

31. Kappos L, Polman CH, Freedman MS, Edan G, Hartung HP, Miller DH, et al. Treatment With Interferon beta-1b Delays Conversion to Clinically Definite and McDonald MS in Patients With Clinically Isolated Syndromes. Neurology (2006) 67:1242-9. doi: 10.1212/01.wnl.0000237641.33768.8d

32. Russell MW, Moldoveanu Z, Ogra PL, Mestecky J. Mucosal Immunity in COVID-19: A Neglected But Critical Aspect of SARS-CoV-2 Infection. Front Immunol (2020) 11:611337. doi: 10.3389/fimmu.2020.611337

33. Alibek K, Tskhay A. Ahead of a Vaccine: A Safe Method of Protection Against COVID-19 Exists. Res Ideas Outcomes (2020) 6:61709. doi: 10.3897/ rio.6.e61709

34. Turner RB, Felton A, Kosak K, Kelsey DK, Meschievitz CK. Prevention of Experimental Coronavirus Colds With Intranasal -2b Interferon. J Infect Dis (1986) 154:443-7. doi: 10.1093/infdis/154.3.443

35. Kugel D, Kochs G, Obojes K, Roth J, Kobinger GP, Kobasa D, et al. Intranasal Administration of Alpha Interferon Reduces Seasonal Influenza A Virus Morbidity in Ferrets. J Virol (2009) 83:3843-51. doi: 10.1128/jvi.02453-08

36. Scagnolari C, Vicenzi E, Bellomi F, Stillitano MG, Pinna D, Poli G, et al. Increased Sensitivity of SARS-coronavirus to a Combination of Human Type I and Type II Interferons. Antivir Ther (2004) 9:1003-11.

37. Mantlo E, Bukreyeva N, Maruyama J, Paessler S, Huang C. Antiviral Activities of Type I Interferons to SARS-CoV-2 Infection. Antiviral Res (2020) 179:104811. doi: 10.1016/j.antiviral.2020.104811

38. Cinatl J, Morgenstern B, Bauer G, Chandra P, Rabenau H, Doerr HW. Treatment of SARS With Human Interferons. Lancet (2003) 362:293-4. doi: 10.1016/S0140-6736(03)13973-6

39. Monk PD, Marsden RJ, Tear VJ, Brookes J, Batten TN, Mankowski M, et al. Safety and Efficacy of Inhaled Nebulised Interferon beta-1a (SNG001) for Treatment of SARS-CoV-2 Infection: A Randomised, Double-Blind, PlaceboControlled, Phase 2 Trial. Lancet Respir Med (2020) 9:196-206. doi: 10.1016/ S2213-2600(20)30511-7

40. van der Made CI, Simons A, Schuurs-Hoeijmakers J, van den Heuvel G, Mantere T, Kersten S, et al. Presence of Genetic Variants Among Young Men With Severe Covid-19. JAMA (2020) 324:663-73. doi: 10.1001/ jama.2020.13719

41. Xia H, Shi P-Y. Antagonism of Type I Interferon by Severe Acute Respiratory Syndrome Coronavirus 2. J Interf Cytokine Res (2020) 40:543-8. doi: 10.1089/ jir.2020.0214

42. Castro-Borrero W, Graves D, Frohman TC, Flores AB, Hardeman P, Logan D, et al. Current and Emerging Therapies in Multiple Sclerosis: A Systematic Review. Ther Adv Neurol Disord (2012) 5:205-20. doi: 10.1177/ 1756285612450936

43. Dorgham K, Neumann AU, Decavele M, Luyt C-E, Yssel H, Gorochov G. Considering Personalized Interferon Beta Therapy for COVID-19. Antimicrob Agents Chemother (2021) 65:e00065-21. doi: 10.1128/aac.00065-21

44. Taylor MM, Kobeissi L, Kim C, Amin A, Thorson AE, Bellare NB, et al. Inclusion of Pregnant Women in COVID-19 Treatment Trials: A Review and
Global Call to Action. Lancet Glob Heal (2020) 9:e366-71. doi: 10.1016/S2214109X(20)30484-8

45. Onabajo OO, Banday AR, Stanifer ML, Yan W, Obajemu A, Santer DM, et al. Interferons and Viruses Induce a Novel Truncated ACE2 Isoform and Not the Full-Length SARS-CoV-2 Receptor. Nat Genet (2020) 52:1283-93. doi: 10.1038/s41588-020-00731-9

46. Hou YJ, Okuda K, Edwards CE, Martinez DR, Asakura T, Dinnon KH, et al. SARS-Cov-2 Reverse Genetics Reveals a Variable Infection Gradient in the Respiratory Tract. Cell (2020) 182:429-46.e14. doi: 10.1016/j.cell.2020.05.042

47. Higgins TS, Wu AW, Illing EA, Sokoloski KJ, Weaver BA, Anthony BP, et al. Intranasal Antiviral Drug Delivery and Coronavirus Disease 2019 (Covid-19): A State of the Art Review. Otolaryngol Neck Surg (2020) 163: 019459982093317. doi: 10.1177/0194599820933170

48. Zhou Q, Chen V, Shannon CP, Wei X-S, Xiang X, Wang X, et al. Interferon$\alpha 2 b$ Treatment for COVID-19. Front Immunol (2020) 11:1061. doi: 10.3389/ fimmu.2020.01061

49. Brzoska J, Von Eick H, Hündgen M. Interferons in the Therapy of Severe Coronavirus Infections: A Critical Analysis and Recollection of a Forgotten Therapeutic Regimen With Interferon Beta. Drug Res (Stuttg) (2020) 70:2917. doi: 10.1055/a-1170-4395

50. Song K, Yoon I-S, Kim NA, Kim D-H, Lee J, Lee HJ, et al. Glycoengineering of Interferon- $\beta$ 1a Improves its Biophysical and Pharmacokinetic Properties. PloS One (2014) 9:e96967. doi: 10.1371/journal.pone.0096967

51. Zhou Z, Ren L, Zhang L, Zhong J, Xiao Y, Jia Z, et al. Heightened Innate Immune Responses in the Respiratory Tract of COVID-19 Patients. Cell Host Microbe (2020) 27:883-90.e2. doi: 10.1016/j.chom.2020.04.017

52. Lee JS, Shin E-C. The Type I Interferon Response in COVID-19: Implications for Treatment. Nat Rev Immunol (2020) 20:1-2. doi: 10.1038/s41577-02000429-3

53. Lee JS, Park S, Jeong HW, Ahn JY, Choi SJ, Lee H, et al. Immunophenotyping of COVID-19 and Influenza Highlights the Role of Type I Interferons in Development of Severe COVID-19. Sci Immunol (2020) 5:1554. doi: 10.1126/ sciimmunol.abd1554

54. Bastard P, Rosen LB, Zhang Q, Michailidis E, Hoffmann H-H, Zhang Y, et al. Auto-Antibodies Against Type I Ifns in Patients With Life-Threatening COVID-19. Science (2020) 65:eabd4585. doi: 10.1126/science.abd4585

55. Wang N, Zhan Y, Zhu L, Hou Z, Liu F, Song P, et al. Retrospective Multicenter Cohort Study Shows Early Interferon Therapy is Associated With Favorable Clinical Responses in COVID-19 Patients. Cell Host Microbe (2020) 28:45564.e2. doi: 10.1016/j.chom.2020.07.005

56. Wise J. Covid-19: New Coronavirus Variant is Identified in UK. BMJ (2020) 371:m4857. doi: 10.1136/bmj.m4857

Conflict of Interest: The authors declare that the research was conducted in the absence of any commercial or financial relationships that could be construed as a potential conflict of interest.

Copyright (c) 2021 Lee, Jeong, Lee, Jang, Zheng, Kwon and Repine. This is an open-access article distributed under the terms of the Creative Commons Attribution License (CC BY). The use, distribution or reproduction in other forums is permitted, provided the original author(s) and the copyright owner(s) are credited and that the original publication in this journal is cited, in accordance with accepted academic practice. No use, distribution or reproduction is permitted which does not comply with these terms. 